\title{
DISCOURSE ANALYSIS IN LINGUISTIC EXPERTISE OF MEDIA TEXTS WITH NATIONALISTIC CONTENT ${ }^{1}$
}

\author{
Liliia R. Duskaeva \\ Saint Petersburg State University, Saint Petersburg, Russia
}

\begin{abstract}
The purpose of the study was to determine the peculiarities of the discursive method when it is applied in linguistic expertise practice. The method is considered a special type of the text interpretation as it allows to diagnose the nationalist-and-extremist orientation of the text. Discourse analysis includes a number of procedures which are consistently carried out, the most important among mentioned procedures are: 1) selection of the most important semantic components of the text; 2) identification among them of those charged with the modus of rejection and hostility; 3) assessment of language structures for the delict content in them; 4) justification of delict presence in statements, which is based on the analysis of the structure of the speech situation in case of delict detection. Thus, the expertise discourse analysis is the determination of those peculiarities in the selection and combination of language means that form the conflictogenicity of the text modus. Such a modus is formed with expression of dislike and hatred to another nation, affirming the idea of the exclusivity of one's own nation, and encouraging aggressive actions, which are expressed by the impelling compositional forms of appeal, proclamation, instruction, advice, warning, demand, threat. Each of the forms is characterized by its own configuration of ways and means. The author of the article analyzed two cases with conflictogenic texts. In the first case, discourse analysis confirmed the presence of delict, in the second case its absence was demonstrated.

Key words: discourse, discourse analysis, legal text interpretation, linguistic expertise, discursive-and-stylistic analisis, delict.

Citation. Duskaeva L.R. Discourse Analysis in Linguistic Expertise of Media Texts with Nationalistic Content. Vestnik Volgogradskogo gosudarstvennogo universiteta. Seriya 2. Yazykoznanie [Science Journal of Volgograd State University. Linguistics], 2020, vol. 19, no. 1, pp. 52-63. (in Russian). DOI: https://doi.org/10.15688/ jvolsu2.2020.1.5
\end{abstract}

\section{ДИСКУРСИВНЫЙ АНАЛИЗ ТЕКСТОВ НАЦИОНАЛИСТИЧЕСКОЙ НАПРАВЛЕННОСТИ В ПРАКТИКЕ ПРОВЕДЕНИЯ ЛИНГВИСТИЧЕСКОЙ ЭКСПЕРТИЗЫ ${ }^{1}$}

\author{
Лилия Рашидовна Дускаева \\ Санкт-Петербургский государственный университет, г. Санкт-Петербург, Россия
}

\begin{abstract}
Аннотация. Цель проведенного исследования - установление особенностей использования дискурсивного метода в лингвоэкспертной практике. Будучи особым способом интерпретации текста, данный ㄱ метод позволяет диагностировать националистически-экстремистскую направленность текстов. Дискурсণิ Оิ анализ включает ряд последовательно осуществляемых процедур, важнейшими среди которых являются: ـ 1) установление смысловой структуры текста через вычленение важнейших смыслов текста; 2) определение в этой структуре мыслительных структур, заряженных модусом неприятия и вражды; 3) оценка языковых структур на предмет содержания в них деликтности; 4) в случае обнаружения последней обоснование ее присутствия в высказываниях с опорой на анализ структуры речевой ситуации. Тем самым экспертный д дискурс-анализ представляет установление тех особенностей в отборе и сочетании языковых средств, кото() рые формируют конфликтогенность модуса текста. Такой модус создается выражением неприязни и нена-
\end{abstract}


висти к другой нации, утверждением идеи исключительности своей нации, побуждением к агрессивным действиям, которые выражаются побудительными композиционными формами призыва, воззвания, поучения, совета, предостережения, требования, угрозы. Каждая из форм характеризуется своей конфигурацией способов и средств. Возможности метода показаны на примере анализа двух кейсов: в одном случае наличие деликта в текстах подтверждено, в другом - опровергнуто.

Ключевые слова: дискурс, дискурсивный анализ, интерпретация правового текста, лингвистическая экспертиза, дискурсно-стилистический анализ, деликт.

Цитирование. Дускаева Л. Р. Дискурсивный анализ текстов националистической направленности в практике проведения лингвистической экспертизы // Вестник Волгоградского государственного университета. Серия 2, Языкознание. - 2020. - T. 19, № 1. - C. 52-63. - DOI: https://doi.org/10.15688/jvolsu2.2020.1.5

\section{Введение}

Как показывает опыт проведения экспертиз, дискурсивный метод является основным при диагностировании целого ряда речевых преступлений [Мишланов, Голованова, Салимовский, 2011; Чернышова, 2016]. Однако чтобы разобраться в том, как он может быть использован в ходе экспертного анализа, необходимо хотя бы контурно дать определение дискурса в силу того, что в современной отечественной науке это понятие - одно из наиболее релятивных.

Лингводискурсологические исследования с момента зарождения были направлены на установление структурной системности дискурса. М. Фуко, один из создателей французской школы дискурса, рассматривал дискурс как «сложную и дифференцируемую практику, подчиняющуюся доступным правилам и трансформациям, управляющую поведением тех, кто в него включен, создавая таким образом неразрывную связь с социальной реальностью» [Фуко, 1996, с. 8], выражающуюся в «своих собственных формах сцепления и последовательностей» [Фуко, 1996, с. 8]. В лингвистических трактовках сторонников М. Фуко различаются векторы анализа структуры дискурсной формации (системности), а потому и процедура ее описания в различных концепциях неодинакова. Поскольку именно эти векторы определяют методы дискурсивного анализа языкового материала, назовем три наиболее широко распространенных из них, важных для разработки дискурсивной методики лингвистической экспертизы.

В отечественной лингвистике едва ли не одно из первых определений дискурса дал В.3. Демьянков. Он связал его проявления с образующимися вокруг общего концепта пос- ледовательностями пропозиций и открыл элементы его смысловой структуры - события и «не-события»: «Discours - дискурс... часто... концентрируется вокруг некоторого опорного концепта; создает общий контекст, описывающий действующие лица, объекты, обстоятельства, времена, поступки и т. п., определяясь не столько последовательностью предложений, сколько тем общим для создающего дискурс и его интерпретатора миром, который “строится" по ходу развертывания дискурса. Исходная структура дискурса имеет вид последовательности элементарных пропозиций, связанных между собой логическими отношениями конъюнкции, дизъюнкции и т. п. Элементы дискурса: излагаемые события, их участники, перформативная информация и “не-события", то есть: а) обстоятельства, сопровождающие события; б) фон, проясняющий события; в) оценка участников события; г) информация, соотносящая дискурс с событиями» [Демьянков, 1982, с. 75]. В определении принципиальна идея о том, что дискурсную формацию создает речевая практика - общность контекста, который составляют последовательности элементарных пропозиций, объединенные опорным концептом и фрагментом внеязыковой действительности.

В появившемся позже определении Н.Д. Арутюновой, ставшем хрестоматийным, дискурс уже связан с текстом, а между понятиями «текст» и «речь» более четко установлены синонимичные отношения: «Дискурс связный текст в совокупности с экстралингвистическими - прагматическими, социокультурными, психологическими и др. факторами; текст, взятый в событийном аспекте; речь, рассматриваемая как целенаправленное социальное действие, как компонент, участвующий во взаимодействии людей и механизмах их со- 
знания (когнитивных процессах). <..> Дискурс - это речь, “погруженная в жизнь”» [Арутюнова, 1990, с. 136-137].

Связь текста и дискурса была уточнена Ю.С. Степановым: «Дискурс существует прежде всего и главным образом в текстах, но таких, за которыми встает особая грамматика, особый лексикон, особые правила словоупотребления и синтаксиса, особая семантика, - в конечном счете - особый мир. В мире всякого дискурса действуют свои правила синонимичных замен, свои правила истинности, свой этикет. Это - “возможный (альтернативный) мир" в полном смысле этого логикофилософского термина. Каждый дискурс - это один из “возможных миров"» [Степанов, 1995, c. 44-45]. Дискурс, отражая в текстах один из «возможных миров», формирует в нем правила социального взаимодействия, несет на себе печать этих правил в «особых» отборе и употреблении языковых средств и способов выражения. Задача лингвиста - в ходе интерпретации текстов, раскрывающих «мир» дискурса, понять его формацию, специфику отбора и употребления используемых для этого языковых средств.

Тот дискурсивный мир, с которым имеет дело лингвист-эксперт, заряжен модусом вражды, задача эксперта - понять, совершается ли в результате создания мира дискурса речевое преступление. С этой целью анализируются средства воссоздания элементов дискурса - излагаемых событий, их участников, перформативной информации и «не-событий», а именно: а) обстоятельств, сопровождающих события; б) фона, проясняющего события; в) оценки участников события; г) информации, соотносящей дискурс с событиями. Экспертный анализ дискурсивного мира это установление тех особенностей в отборе и сочетании языковых средств, которые создают конфликтогенный эффект.

\section{Материал и методы исследования}

Как показывает практика выполнения экспертиз, дискурсивный метод эффективен при диагностировании у медиатекстов националистически-экстремистской направленности. При проведении лингвистической экспертизы текстов их дискурсивный анализ пред- стает как особый способ интерпретации, цель которого - установить наличие / отсутствие в текстах лингвистических признаков конфликтности, что, по мнению Т.В. Чернышовой, составляет первый этап лингвистической экспертизы [Чернышова, 2016, с. 336]. Однако дискурсивный анализ используется шире. Поскольку «одной своей стороной дискурс обращен к прагматической ситуации, которая привлекается... для его интерпретации» [Арутюнова, 1990, с. 137], а «другой своей стороной обращен к ментальным процессам участников коммуникации: к... правилам и стратегиям порождения и понимания речи в тех или иных условиях» [Арутюнова, 1990, с. 137], вполне логичен подход к анализу дискурса, базирующемуся на рассмотрении взаимодействия и пересечения четырех структур: 1) структуры идей, выражаемых в тексте; 2) структуры мыслительных процессов говорящего; 3) языковых структур, используемых говорящим; 4) структуры речевой ситуации (отношение между говорящим и слушающим) [Кибрик, Плунгян, 1997]. Далее смоделируем этот подход применительно к лингвоэкспертной практике.

При лингвоэкспертном диагностировании у медиатекстов националистически-экстремистской направленности эти процедуры принимают следующий вид: 1) установление смысловой структуры текста, вычленяющее важнейшие смыслы текста; 2) выявление в этой структуре мыслительных структур, заряженных модусом неприятия и вражды; 3) оценка языковых структур на предмет содержания в них деликтности; 4) в случае обнаружения последней обоснование ее присутствия в высказываниях с опорой на анализ структуры речевой ситуации. Таким образом, как научный метод дискурс-анализ включает ряд последовательно осуществляемых процедур.

Установление «структуры идей» в этом дискурсе возможно через реконструкцию иерархии типовых интенций (дискурсных правил), организующих дискурс [Ушакова, Павлова, 2000]. Для этого у каждого текста выявляется содержательная макроструктура и представляющие ее микроструктуры. В ходе выделения структур, заряженных модусом неприятия - экстремизма и национализма, раскрываются конфликтогенные социальные 
смыслы (контекстуальные, ситуативные), лежащие в основе создания текста. Онтологическое свойство медиатекстов, направленных на открытое утверждение социальной позиции, - заряженность полемичностью, часто остроконфликтной. Задача эксперта - выявить в конфликтности деликтность, то есть, в соответствии с Уголовным кодексом РФ, возбуждение национальной, расовой, религиозной вражды, которая приводит к унижению национального достоинства; к утверждению исключительности, превосходства либо неполноценности граждан по признаку их отношения к религии или расовой принадлежности; к оправданию призывов к преступным действиям.

Каждая из указанных характеристик уточняется в методических рекомендациях Генеральной прокуратуры Российской Федерации «Об использовании специальных познаний по делам и материалам о возбуждении национальной, расовой или религиозной вражды» [Методические рекомендации...]. Например, «возбуждающей в смысле ст. 282 УК РФ» в этих рекомендациях рассматривается информация, «которая содержит отрицательную эмоциональную оценку и формирует негативную установку в отношении определенной этнической (национальной), расовой (антропологической), конфессиональной (религиозной) группы или отдельных лиц как членов этой группы, подстрекает к ограничению их прав или к насильственным действиям против них» [Методические рекомендации...]. Следовательно, возбуждение вражды усматривается в модусах отрицательной эмоциональной оценки и подстрекательства. Модус отрицательной оценочности проявляется в дискурсе в отрицательной ценностной ориентации пишущего к предмету речи. Подстрекательство дефинируется в словарях как «побуждение к недозволенным поступкам, преступным действиям» (БТСРЯ). В случае обнаружения в дискурсе модальности вражды далее проверяется, соотносятся ли эти интенции с указанным в ст. 282 УК РФ референтом - нацией в целом или отдельным ее представителем. Выявление референта, на которого направлены иллокутивные смыслы, способствует восстановлению «структуры мыслительных процессов говорящего».
В лингвоэкспертной практике руководствуются «дискурсивным» разъяснением содержания термина «пропаганда» в отношении к разжиганию национальной розни, которое дал еще Пленум Верховного суда СССР в Постановлении № 17 от 23 декабря 1988 г. «О рассмотрении судами дел, связанных с преступлениями, совершенными в условиях стихийного или иного общественного бедствия». В документе уточняются каналы и способы распространения пропаганды: публичные выступления и призывы, в том числе в печати и иных средствах массовой информации, изготовление и распространение листовок, плакатов, лозунгов и т. п., а также организация «собраний, митингов, демонстраций» и «активное в них участие в вышеуказанных целях». В тексте закона от 25 июля 2002 г. № 114-Ф3 «О противодействии экстремистской деятельности» обнаруживаем уточнения признаков пропагандистского националистического дискурса. С точки зрения законодателя, такой дискурс формируется в ходе «распространения злонамеренных слухов и измышлений, подрывающих доверие и уважение к другой национальности, вызывающих чувство неприязни к ней», а также в ходе «распространения среди широкого круга лиц идей, взглядов, представлений или побуждений к действиям, направленных на возбуждение национальной, расовой или религиозной вражды», а формами презентации такого дискурса выступают «призывы, воззвания, поучения, советы, предостережения, требования, угрозы и т. п.» [Методические рекомендации...]. Опираясь на текст закона, приходим к выводу, что дискурс пропаганды национализма осуществляет открытое речевое воздействие с целью формирования общественного мнения через каналы средств массовой коммуникации модусом враждебности - неприязни и ненависти к другой нации, утверждения идеи исключительности своей нации, побуждения к агрессивным действиям, которые выражаются композиционными формами призыва, воззвания, поучения, совета, предостережения, требования, угрозы.

Обращаясь к анализу языковых структур, выступающих носителями характерной для дискурсной формации иллокуций враждеб- 
ности, эксперт особенное внимание уделяет средствам, с помощью которых устанавливается связь отношений между враждебно настроенным автором и объектом, на который враждебность направлена. Выделение в дискурсной формации компонентов, несущих информацию о враждебном «отношении между говорящим и предметом речи», способствует уточнению конфликтогенных компонентов не только содержательно-смысловой, но и языковой структуры дискурса. В случае, если устанавливается присутствие деликтов в дискурсе, приступают к анализу значений используемых языковых средств.

Языковые средства, заряженные направленным на какую-либо нацию модусом неприятия: резко отрицательной оценки, враждебной эмотивности («издевки», грубости, «отвращения или презрения»), агрессивной побудительности (в призыве, воззвании, поучении, совете, предостережении, требовании, угрозе), оправдании призывов к преступным действиям, - диагностируют речевое преступление. Следовательно, дискурс-анализ, связанный с поиском средств выражения характерных для дискурса признаков, важен не только на первом этапе лингвистической экспертизы. Дискурсивный подход позволяет обнаружить источник деликтности в пропагандистской речевой деятельности - в организации нарративов, в динамике модусов изложения, в семантико-речевой организации призывов.

\section{Результаты и обсуждение}

Возможности дискурсивного метода продемонстрируем в ходе анализа конкретных конфликтогенных текстов. В первом случае рассмотрим пример анализа текстов, содержащих националистически-экстремистский заряд, во втором случае - пример анализа текста, в котором конфликтогенность не обнаружена.

\section{Пример первый}

Эксперту был предложен для анализа дискурс форума, включавший семь публикаций, размещенных в сети Интернет на специально организованной площадке. Во всех семи публикациях выражено враждебное от- ношение к России и русским. Осмотр и предварительное исследование материалов показывают, что все они представляют собой паблики, предназначенные для распространения в социальной сети. Первый озаглавлен «Казламордый достаток, или как русофобы с жиру бесятся!», второй и третий тексты без названий представляют собой комментарии сообщений российской прессы, четвертый текст имеет название "Дно победобесия», пятый - «ЖИВОТНЫЕВАИВАЛЕ!», название шестого - «Всем "ярузке оккупантам" на заметку», седьмого - «Крымские спортсмены, или цена предательства». В приводимых примерах орфография и пунктуация источников сохранены. Материалы были размещены в сети: http://botsman-katsman.com/ face-of-katsapi/454-krymskie-sportsmenY-ilicenapredatelstva; http://botsman-katsman.com/ video/453-vsem-varuzke-okkupantam-nazametku.html; http://botsman-katsman.com/ katsapi-now/409-dno-pobedobesiya.html; http:// botsman-katsman.com/katsapi-now/390kazlamordvv-dostatok-ili-kakmsofoby-s-zhirubesyatsya.html.

Вопросы, на которые должен был дать ответы эксперт:

1. Имеются ли в представленных текстах признаки возбуждения розни (вражды, ненависти) в отношении группы лиц по признаку пола, расы, национальности, отношения к религии, принадлежности к социальной группе?

2. Содержатся ли в представленных на исследование информационных материалах признаки пропаганды превосходства, исключительности либо неполноценности какой-либо расовой, национальной, религиозной или социальной группы?

Экспертный анализ содержания дискурса для ответа на первый вопрос. Все семь текстов представляют собой медиатексты - паблики, которые распространяются в социальной сети и доступны широким массам читателей. В диалоге эти тексты занимают позицию реплики-стимула и предназначены для получения последующих откликов на них. Провокативность содержания пабликов очевидна и вычитывается уже из заголовков.

В первом тексте под названием «Казламордый достаток, или как русофобы с жиру 
бесятся!» основной модус - издевка, направленная на высказывания российских чиновников об экономической мощи России. Ключевая идея текста: утверждение русских о богатстве своей страны - бахвальство. Она выражена прежде всего в высказывании: Россия - caмый крупный мыльный пузырь нашей $c$ вами современности, за помпезно-имперской оболочкой которого, по сути, нет ничего, кроме трухлявой пустоты. В этом предложении лексема Россия употреблена в позиции субъекта, а в позиции предиката, указывающего на важнейшее свойство субъекта, использована уничижительно-оценочная метафора. Ее отрицательный заряд усилен суперлативом самый крупный, саркастичной антитезой, организованной антонимичными метафорическими именами (оболочка - пустота) и определениями (помпезно-имперская трухлявая).

Второй текст направлен на высмеивание утверждения о богатствах России. Среди материалов приведен скриншот газетной публикации под заголовком «В Волгограде 24-летняя многодетная мать повесилась изза нищеты». Модус издевки в авторском комментарии новости создается утверждениями о том, что такие трагедии среди нищих россиян часты, они свидетельствуют о крайне бедственном положении российской экономики.

В третьем тексте разговор о России продолжается в тоне издевки. Его основная модальность - высмеивание заявления депутата Макарова о том, что Россия «купается в деньгах». В четвертом и пятом текстах («Дно победобесия», «ЖИВОТНЫЕВАИВАЛЕ!») автор эксплицирует саркастическое отношение к традиции празднования россиянами Дня Победы. В тексте «Всем "ярузке оккупантам" на заметку» блогер полемизирует с существующим в русском массовом сознании мифом о том, что русские вели только освободительные войны, в то время как, по его мнению, всегда были агрессорами и вели лишь захватнические войны. Автор считает справедливым отрицательное отношение ко всем русским со стороны всех народовсоседей России. В седьмом тексте «Крымские спортсмены, или цена предательства» со злорадством выражено удовлетворение тем, что крымские спортсмены, как и все российские, не допущены к участию в Олимпиаде 2018 года.

Содержательно и формально все проанализированные тексты направлены на пропаганду, с помощью которой в массовом сознании формируется и подкрепляется отрицательный образ русских. Это намерение прочитывается уже в саркастических и бранных заголовках. Коммуникативный замысел автора дискурса - передать презрительное отношение к России и русским. Реконструкция интенций предложенных семи текстов форума показывает, что всех их отличает экспрессивная, крайне агрессивная форма выражения враждебности к русским и к России: русским приписываются пустое хвастовство, стремление гиперболизировать достоинства своей страны, враждебные для всех соседей бравада и патриотизм, недружелюбные действия по отношению к народам всех соседних стран; все сегодняшние несчастья народов соседних стран объясняются агрессивностью русских в прошлом, настоящем, будущем. В ходе содержательного анализа приходим к выводу, что тексты конфликтогенны, поскольку они не только выражают вражду, но и имеют экстремистски-националистическую заряженность.

Последнее проявилось в такой дискурсной организации нарративов об исторических событиях, чтобы иметь возможность обвинить русских во враждебности к соседям России. Например, русским приписывается презрительное именование соседей: они искренне верят в то, что все их соседи, и в первую очередь ненавистные укры-грузины-прибалты, а также прочие пиеки, спят и регулярно видят сны о том, как бы им поскорее приобщиться $\kappa$ этому благополучию; русских с помощью пейоративной, бранной, нецензурной лексики обвиняют в нравственной неполноценности: русскомирский п...и, мельдониевую п...добратию, предательство; ..вожди Русского Мира, уже достаточно давно нашупав слабые струны примитивных казламордых душ, мастерски разыгрывают на них иелье симфонии воспевающие дутое величие страны-бензоколонки; каиапня не испытывает дефицита в грязи 
u гОвнах; русским указывается на умственную неполноценность через бранные отрицательно-оценочные определения, в том числе окказиональные: дебиловатая, лаптеносная, полупустые черепушки, грязная (кацапня), примитивные казламордые души; примитивны; ...это нечистоплотное племя пожирателей репь настолько обнаглело в своем слабоумии, что не только верит в откровенно пропагандонские сказки в духе "орды русских оккупантов врывались в стойбища, ауль и кишлаки, оставляя после себя больниць, фабрики и музеи“ (с), но и на полном серьезе требует к себе уважения и даже почитания со стороны тех, по чьей земле им удалось потоптаться!

Дискурс содержит брань, направленную против русских: ...главное, чтоб моча была с привкусом имперства и достаточно горячей для того, чтоб в ней можно было заварить пачку заплесневелого «доширака»! Нет среди них людей - все они не более чем унтерменши, выродки и казламордая нечисть, которую ни в коем случае нельзя подпускать к себе ближе, чем на пушечный выстрел!; презрительные номинации русских: президент России - главный рассадник русского мира, Россия - Казламордая Зашкварашка, русские - кацапня, среднестатистические кацапь; оценки русских зоосемантическими метафорами: современная Зашкварашка выглядит как вечно обоссаная страна-петух, вечно опущенный народ-пидорас; ЖИВОТНЫЕВАИВАЛЕ! Русский ребенок называется личинкой ватника, а русские - жалким племенем казламордых недоумков; приписываемая русским ущербность поддерживается их внешними характеристиками: с внешностью, образом мыслей, а также традициями и повадками мало чем похожи на людей и в глазах современного циивилизованного человечества выглядят не более чем непредсказуемыми и дурно пахнущиими двуногими животными, которых кто-то шутки ради нарядил в человеческую одежду.

Все перечисленные средства и приемы признаются инвективными [Понятие чести..., 1997]. В совокупности они формируют дискурсную формацию, которую отличает вуль- гарное выражение модуса вражды, для чего мобилизовано большое число сниженных языковых ресурсов: арготическая и обсценная лексика, резко отрицательно-оценочная метафоричность, сниженный, разговорный синтаксис, грубые окказионализмы. Отрицательное отношение к русским выражается не только оценками, но и эмотивными компонентами модусного значения: дискурс насыщен эмоциями ненависти, презрительного гнева, злорадства.

Экспертный анализ дискурса для ответа на второй вопрос. Несмотря на крайне невежественную, отталкивающую форму речевого воздействия, осуществляемого этими текстами, оно имеет признаки пропаганды, поскольку тексты размещены в сети Интернет на специально отведенной площадке в социальных сетях, к которым открыт доступ всем желающим.

Признаки пропаганды в рассматриваемых нами текстах следующие: 1) устремленность влиять на адресата внушением неприязни и ненависти к русским через нарративы, демонстрирующие отрицательные качества всех русских; 2) усиливает пропагандистское воздействие материалов прямая адресованность к аудитории, выраженная, например, в повторах местоименных форм 2-го лица: Каждый из Вас может внести свой вклад в развитие Науки на странище «ПОМОЩЬ ПРОЕКТУ». Также предлагаем вам посетить филиал Лаборатории Боимана Каймана в Живом Журнале! И конечно не забывайте о том, чmo y нас menерь есть СВОЙ ФОРУМ!; $3)$ привлекает большое число читателей крайне грубая, примитивная оценка фактов, сообщенных СМИ, а ненависть, враждебное отношение к русским усиливается в текстах трэш-экспрессией (эстетикой безобразного), например: Глядя на две эти новости прям даже и не знаю, что предположить - то ли волгоградская кацапка оказалась какойто жилобанлеровской русофобкой, которая явно бесясь с жиру решила повеситься исключительно для того, чтобы бросить пятно на светлый лик Русского Мира, то ли путинский пудель Андрей Макаров все таки нагло и цинично п...m?! Впрочем, какие бы ни были мои предположения, они все равно никак не повлияют на уверен- 
ность жалкого племени казламордых недоумков в том, что их убогая недострана является сверхдержавой, а весь мир им завидует - одним словом, неизлечимые дебиль, б...ь (c), которым запросто можно ссать в уши не только о чем угодно, но и сколь угодно долго, главное чтоб моча была с привкусом имперства и достаточно горячей для того, чтоб в ней можно было заварить пачку заплесневелого “доширака"!; 4) высокий градус враждебности дискурса выступает обоснованием для поддержки и оправдания в массовом сознании украинцев провокационных действий властей этой страны против России.

Наличие в текстах перечисленных выше примет дает основание положительно ответить на вопрос о наличии в тексте признаков пропаганды национальной вражды к русским.

Выводы. Итак, на вопросы «Имеются ли в представленных текстах признаки возбуждения розни (вражды, ненависти) в отношении группы лиц по признаку пола, расы, национальности, отношения к религии, принадлежности к социальной группе?» и «Содержатся ли в представленных на исследование информационных материалах признаки пропаганды превосходства, исключительности либо неполноценности какой-либо расовой, национальной, религиозной или социальной группы?» эксперт дал положительные ответы.

\section{Пример второй}

Для анализа дан информационный материал, размещенный в сети Интернет.

Эксперту предложено ответить на вопрос: содержатся ли в представленном информационном материале сведения о том, что лицо, о котором идет речь, призывает к враждебным (насильственным) действиям над физическими лицами или группами лиц, призывает к уничтожению материальных объектов, призывает к организации преступного сообщества для совершения террористической акции или участия в ней?

Чтобы ответить на такой вопрос, необходимо проанализировать текст, ответив на ряд дополнительных вопросов: названо ли в тексте именами собственными конкретное лицо как субъект ряда действий? являются ли приписываемые этому субъекту действия призывом к враждебным (насильственным) действиям над физическими лицами или группами лиц, к уничтожению материальных объектов или к организации преступного сообщества для совершения террористической акции или участия в такой акции? Иными словами, необходимо выяснить, содержится ли в высказывании утверждение о причастности определенного лица к призывам к террористическим действиям.

В ходе анализа текст был поделен на три части. Первая представляет собой разоблачение, вторая - обвинение, а третья - призыв. Продемонстрируем это.

В первой части в разоблачительном нарративе о некой организации идет речь о том, что она маскирует разрушительные цели под видом религиозных:

(1) Мы видим как на наших глазах формируется под видом религиозной новая террористическая организация. Не имеющая отношения ни к российским традициям, ни к истинному православию. Их интересует лишь дистабилизация (так в источнике. - Л. Д.) в обществе, насилие, война.

Выделенные лексемы указывают на преступные цели организации. Дана обобщающая характеристика этих целей в лексеме террористическая, подчеркивающей преступность организации. Мысль о том, что, действуя под видом религиозной, организация скрывает истинные цели, акцентируется отрицательной конструкцией с двойным отрицанием не имеющиая отношения ни к российским традицияя, ни к истинному православию, подчеркивается усилительной частицей лишь, использованием рядов однородных членов предложения с повторяющимся союзом. Употребленные в тексте лексемы террористическая, дестабилизация (как нарушение равновесия), насилие, война называют отрицательно оцениваемые процессы, которые могут включать «враждебные (насильственные) действия над физическими лицами или группами лиц», «уничтожение материальных объектов», «организацию преступного сообщества для совершения террористической акции или участия в такой акции» [Методические рекомендации...], но могут и не включать. Ср. с теми 
значениями указанных слов, в которых они выступают в следующих контекстах: холодная война, информационная война, телефонный террор, коммуникативный террор. Таким образом, утверждение автора анализируемого высказывания о том, что у некой организации он обнаруживает устремленность к дестабилизации, войне, террору, не означает, что эта организация «призывает к враждебным (насильственным) действиям над физическими лицами или группами лиц, призывает к уничтожению материальных объектов, призывает к организации преступного сообщества для совершения террористической акции или участия в такой акции, по признаку пола, расы, национальности, отношения к религии либо принадлежности к социальной группе» [Методические рекомендации...].

Во второй части предложенного текста вполне определенно назван объект обличения, указывается его должность и фамилия: denyтат Поклонская. Высказывается мысль о ее связи с организацией, деятельность которой направлена на социально осуждаемые цели, утверждается, что депутат Поклонская эту организацию поддерживает:

(2) Мы знаем имена тех, кто стоит за ними. Депутат Поклонская даже не скрывает, что поддерживает данные организации и обеспечивает им прикрытие. «Матильда» - лишь повод для того, чтоб они заявили о себе и меня ужасает, что никто не пытается их остановить. Мы видим и их идеологов, и организаторов, боевиков. Они не скрываются.

Поклонской приписываются два действия поддерживает организации и обеспечивает им прикрытие. По всей видимости, глагол поддержать употреблен здесь в значении 'оказывать помощь, содействие в чем-л.' (ССРЛЯ, с. 335), а сочетание обеспечивать прикрытие $=$ прикрывать - в значении 'скрыть, не дать обнаружить' какие-то преступные действия (БТСРЯ). Осуждение этих действий подчеркнуто с помощью союза даже, субъективно-оценочного меня ужаса$e m$, конструкции с двойным отрицанием никто не nытается. Однако отметим, что в тексте с Поклонской не связываются такие действия, как «призыв к враждебным (насиль- ственным) действиям над физическими лицами или группами лиц, к уничтожению материальных объектов, к организации преступного сообщества для совершения террористической акции или участия в такой акции» [Методические рекомендации...].

Третья часть анализируемого текста представляет собой призыв к насильственному ограничению деструктивных действий, приписываемых представителям указанной в первом речевом действии организации:

(3) Мы видим, что они работают не против кино, они работают против российского государства. Пора уже их остановить!

Речевое действие призыва эксплицировано с помощью конструкции «модальное слово + инфинитив», усилено противительно-отрицательной конструкцией и повтором: работают не против кино, они работают против российского государства, но это не призыв депутата Поклонской к «организации преступного сообщества для совершения террористической акции или участия в ней».

Выводы. Анализируемый текст, обращенный к массовой аудитории, содержит номинацию конкретного лица - депутата Поклонской. Автор анализируемого высказывания утверждает, что это лицо поддерживает и покрывает организации, которым приписывается ряд осуждаемых обществом действий, но в тексте не идет речь о том, что действия, совершаемые самой Поклонской, представляют собой призыв:

- к враждебным (насильственным) действиям над физическими лицами или группами лиц;

- уничтожению материальных объектов;

- организации преступного сообщества для совершения террористической акции или участия в такой акции по признаку пола, расы, национальности, отношения к религии либо принадлежности к социальной группе.

Таким образом, на вопрос «Содержатся ли в представленном информационном материале сведения о том, что лицо, о котором идет речь, призывает к враждебным (насильственным) действиям над физическими лицами или группами лиц, призывает к уничтожению материальных объектов, призывает к организации преступного сообщества для совершения 
Л.Р. Дускаева. Дискурсивный анализ текстов националистической направленности

террористической акции или участия в ней?» экспертом дан отрицательный ответ.

\section{Заключение}

Опыт проведения лингвистических экспертиз показывает, что дискурсивный метод результативен в случае необходимости диагностировать языковые корреляты социальной деятельности, имеющей враждебную коммуникативную направленность. Метод используется на первом этапе судебной экспертизы в качестве диагностирующего конфликтогенность. Однако в случае диагностического экспертного анализа медиатекстов на предмет их экстремистской заряженности, задача которого лишь установить конфликтогенность или ее отсутствие в публикации, метод является основным, поскольку позволяет определить наличие / отсутствие в текстах возбуждения национальной, расовой или религиозной вражды, унижения национального достоинства, пропаганды исключительности, превосходства либо неполноценности граждан по признаку их отношения к религии или расовой принадлежности. Дискурсивный метод при этом включает раскрытие экстремистской направленности в изложении нарративов о событиях, участники которых - представители двух национальных групп: одной приписываются черты исключительности, достоинство другой принижается; в обнаружении модуса презрения, издевки, сарказма с указанием представителя другой национальности, на который эти модусы направлены; в призывах к враждебным действиям против представителей другой национальности разной иллокутивной силы, в оправдании враждебных действий.

Лингвистическими признаками националистически-экстремистского дискурса в текстах модуса неприятия являются: грубая лексика, бранные окказионализмы, которые оскорбляют общественную мораль, нарушают нормы общественных приличий, нецензурные слова. Именно дискурсивный подход с его вниманием к социальным смыслам в высказывании позволяет обнаружить их влияние на денотативный и коннотативный компоненты значений языковых единиц и их недопустимость в конкретном тексте.

\section{ПРИМЕЧАНИЕ}

${ }^{1}$ Исследование проведено при поддержке гранта РФФИ «Создание корпуса официально-деловых текстов русского языка (ОДКРЯ)» (проект № 17-29-09158).

The reported study was funded by the RFBR grant "Creating the Russian Official-Legislative Texts Corpus" (project no. 17-29-09158).

\section{СПИСОК ЛИТЕРАТУРЫ}

Арутюнова Н. Д., 1990. Дискурс // Лингвистический энциклопедический словарь / гл. ред. В. Н. Ярцева. М. : Сов. энцикл. С. 136-137.

Демьянков В. 3., 1982. Морфологическая интерпретация текста и структура словаря // Вопросы кибернетики : Общение с ЭВМ на естественном языке. М. : Науч. совет по комплекс. проблеме «Кибернетика». С. 75-91.

Кибрик А. А., Плунгян В. А., 1997. Функционализм // Фундаментальные направления современной американской лингвистики / под ред. А. А. Кибрика, И. М. Кобозевой, И. А. Секериной. М. : Моск. гос. ун-т им. М.В. Ломоносова, Филол. фак. С. 276-339.

Методические рекомендации Генеральной прокуратуры РФ «Об использовании специальных познаний по делам и материалам о возбуждении национальной, расовой или религиозной вражды». № 27-19-99 от 29.06.1999. URL: http://www.migimo.ru/razdel/137/ (дата обращения: 25.09.2019).

Мишланов В. А., Голованова А. В., Салимовский В. А., 2011. Основы прикладной лингвистики. Теория и практика судебной лингвистической экспертизы текста. Пермь : ПГНИУ. 367 с.

Понятие чести и достоинства, оскорбления и ненормативности в текстах права и средств массовой информации, 1997 / авт.-сост.: А. А. Леонтьев [и др.] ; науч. ред. А. Р. Ратинов. М. : Права человека. $127 \mathrm{c}$.

Степанов Ю. С., 1995. Альтернативный мир, Дискурс, Факт и принцип Причинности // Язык и наука конца XX века : сб. ст. М. : Рос. гос. гуманит. ун-т. С. 44-45.

Ушакова Т. Н., Павлова Н. Д., 2000. Слово в действии. Интент-анализ политического дискурса. СПб. : Алетейя. 320 с.

Фуко М., 1996. Воля к истине. По ту сторону знания, власти и сексуальности. М. : Магистериум - Касталь. 448 с.

Чернышова Т. В., 2016. Аналитико-экспертная деятельность филолога и проблема выбора метода в современной лингвоэкспертной прак- 
тике// ACTALINGUISTICAPETROPOLITANA. Труды Института лингвистических исследований РАН. Т. ХІІ. Ч. 3. СПб. : Наука. С. 335-350.

\section{СЛОВАРИ}

БТСРЯ - Большой толковый словарь русского языка / гл. ред. С. А. Кузнецов. СПб., 1998. Публикуется в авт. ред. 2014 года. URL: http:// gramota.ru/slovari/info/bts/ (дата обращения: 01.06.2019).

ССРЛЯ - Словарь современного русского литературного языка. В 17 т. Т. 11. М. ; Л. : Наука, 1961. 1842 стб.

\section{REFERENCES}

Arutyunova N.D., 1990. Diskurs [Discourse]. Yartseva V.N., ed. Lingvisticheskiy entsiklopedicheskiy slovar [Linguistic Encyclopedic Dictionary]. Moscow, Sovetskaya entsiklopediya Publ., pp. 136-137.

Demyankov V.Z., 1982. Morfologicheskaya interpretatsiya teksta i struktura slovarya [Morphological Interpretation of the Text and Dictionary Structure]. Voprosy kibernetiki: Obshchenie s EVM na estestvennom yazyke [Cybernetics Issues: Communicating with Computers in Natural Language]. Moscow, Nauchnyy sovet po kompleksnoy probleme "Kibernetika", pp. 75-91.

Kibrik A.A., Plungyan V.A., 1997. Funktsionalizm [Functionalism]. Kibrik A.A., Kobozeva I.M., Sekerina I.A., eds. Fundamentalnye napravleniya sovremennoy amerikanskoy lingvistiki [Fundamental Directions of Modern American Linguistics]. Moscow, Moskovskiy gosudarstvennyy universitet im. M.V. Lomonosova, pp. 276-339.

Metodicheskie rekomendatsii Generalnoy prokuratury $\quad \mathrm{RF} \quad$ $O \mathrm{Ob}$ ispolzovanii spetsialnykh poznaniy po delam $i$ materialam o vozbuzhdenii natsionalnoy, rasovoy ili religioznoy vrazhdy». № 27-1999 ot 29.06.1999 [Methodological Recommendations of the General Prosecutor's Office of the Russian Federation "On the Use of Special Knowledge in Cases and Materials on the Initiation of National, Racial or Religious Hostility". No. 27-19-99 of June 29, 1999]. http://www.migimo.ru/ razdel/137/ (accessed 25 September 2019).

Mishlanov V.A. , Golovanova A.V. , Salimovskiy V.A., 2011. Osnovy prikladnoy lingvistiki. Teoriya $i$ praktika sudebnoy lingvisticheskoy ekspertizy teksta [Fundamentals of Applied Linguistics. Theory and Practice of Forensic Linguistic Examination of the Text]. Perm, PGNIU. 367 p.

Leontyev A.A., ed., 1997. Ponyatie chesti $i$ dostoinstva, oskorbleniya i nenormativnosti $v$ tekstakh prava i sredstv massovoy informatsii [Concept of Honor and Dignity, Insults and Profanity in the Texts of Law and the Media]. Moscow, Prava cheloveka. 127 p.

Stepanov Yu.S., 1995. Alternativnyy mir, Diskurs, Fakt i printsip Prichinnosti [Alternative World, Discourse, Fact and the Principle of Causality]. Yazyk $i$ nauka kontsa XX veka: sb. st. [Language and Science of the Late $20^{\text {th }}$ Century. Collected Articles]. Moscow, Rossiyskiy gosudarstvennyy gumanitarnyy universitet, pp. 44-45.

Ushakova T.N., Pavlova N.D., 2000. Slovo v deystvii. Intent-analiz politicheskogo diskursa [Word in Action. Intent-Analysis of Political Discourse]. Saint Petersburg, Aleteyya Publ. $320 \mathrm{p}$.

Fuko M., 1996. Volya $k$ istine. Po tu storonu znaniya, vlasti i seksualnosti [Will to Truth. On the Other Side of Knowledge, Power and Sexuality]. Moscow, Magisterium-Kastal Publ. $448 \mathrm{p}$.

Chernyshova T.V., 2016. Analitiko-ekspertnaya deyatelnost filologa i problema vybora metoda v sovremennoy lingvoekspertnoy praktike [Analytical and Expert Activity of a Philologist and the Problem of Choosing a Method in Modern Linguo-Expert Practice]. ACTA LINGUISTICA PETROPOLITANA. Trudy Instituta lingvisticheskikh issledovaniy RAN. T. XII. Ch. 3 [ACTA LINGUISTICA PETROPOLITANA. Proceedings of the Institute of Linguistic Research of the Russian Academy of Sciences. Vol. XII. Part 3]. Saint Petersburg, Nauka Publ., pp. 335-350.

\section{DICTIONARIES}

Kuznetsov S.A., ed. Bolshoy tolkovyy slovar russkogo yazyka [Great Dictionary of the Russian Language]. Saint Petersburg, 1998. URL: http:/gramota.ru/slovari/info/bts (accessed 1 June 2019).

Slovar sovremennogo russkogo literaturnogo yazyka. V17t. T. 11 [The Dictionary of Modern Russian Literary Language. In 17 Vols. Vol. 11]. Moscow, Leningrad, Nauka Publ., 1961. 1842 cols. 


\section{Information About the Author}

Liliia R. Duskaeva, Doctor of Sciences (Philology), Professor, Department of Medialinguistics, Saint Petersburg State University, Universitetskaya Emb., 7-9, 199034, Saint Petersburg, Russia, 1.duskaeva@spbu.ru,https://orcid.org/0000-0003-3854-2844

\section{Информация об авторе}

Лилия Рашидовна Дускаева, доктор филологических наук, профессор кафедры медиалингвистики, Санкт-Петербургский государственный университет, Университетская наб., 7-9, 199034 г. Санкт-Петербург, Россия, 1.duskaeva@spbu.ru, https://orcid.org/0000-0003-3854-2844 